\title{
Rancang Bangun Peak Flow Meter dengan Output Suara dan Pemantauan Android
}

\author{
Patrisius Kusi Olla*, Wilia Azhar \\ Akademi Teknik Elektromedik (ATEM) Semarang \\ *email: patrisiuskusiolla@gmail.com
}

\begin{abstract}
Peak Flow Meter (PFM) is a tool to measure the amount of air flow in the airway (PFR) and to detect asthma. The output value of PFR can be influenced by several factors, such as age, respiratory muscle strength, height and gender. In this research, airway measurements are used to measure the condition of patients suffering from asthma. The author aims to make this tool so that it can find out how to design and make a peak flow meter output sound tool, measure the peak current and can know how the MPXV7002DP sensor works in regulating output in the form of sound. The method used by the author is to design or make a tool peak flow meter output sound. This MPXV7002DP sensor works when the sensor receives air blows from the flow sensor which automatically reads the highest air pressure from the breath. The test results using the VT Mobile Medical Gas Flow Analyzer prove that the largest percentage error is $2.4 \%$, with the blowing rate on the Peak Flow Meter is $64.0 \mathrm{lpm}$ and the blowing rate on VT mobile is $62.50 \mathrm{lpm}$. Therefore, this tool can be said to be very certain to detect asthma. Then it can be concluded that the peak flow meter is feasible and meets the specified requirements.
\end{abstract}

Keywords - Arduino, Asthma, Bluetooth, MPXV7002DP, PFM, Pressure.

\section{Pendahuluan}

Berdasarkan data WHO Non Communicable Disease di Asia Tenggara diperkirakan bahwa 1,4 juta orang meninggal dunia karena penyakit paru kronik di mana $86 \%$ disebabkan karena penyakit paru obstruktif kronik, dan 7,8\% disebabkan karena asma. WHO fact sheet 2011 menyebutkan bahwa terdapat 235 juta orang menderita asma di dunia, 80\% berada di negara dengan pendapatan rendah dan menengah, termasuk Indonesia. Penyakit saluran pernapasan yang menyebabkan kematian terbesar adalah Tuberculosis $(7,5 \%)$ dan Lower Tract Respiratory Disease (5,1\%) [1].

Penderita asma, sering kali tidak dapat menyadari bahwa dengan aktivitas yang padat dan beberapa gangguan lain dapat membuat kondisi penyakit semakin memburuk dan bahkan kambuh di saat yang tidak terduga, maka perlu pemeriksaan yang rutin. Sering kali faktor biaya yang mahal serta waktu menjadi kendala bagi seseorang untuk melakukan pengobatan yang intensif akibat asma yang di derita. Sehubungan dengan hal itu maka telah dikembangkannya alat yang dapat mengukur arus puncak ekspirasi yang dinamakan Peak Flow Meter (PFM). PFM adalah alat untuk mengukur jumlah aliran udara dalam jalan napas penderita asma sebagai uji tapis penyakit respiratorik. Peak flow meter yang umum di pasaran alat kesehatan adalah masih berupa manual. Tujuan dari penelitian ini adalah mengembangkan penelitian sebelumnya [2], yaitu membentuk Rancang Bangun Peak Flow Meter dengan Output Suara dan Pemantauan Android. 
Beberapa penelitian terdahulu mengembangkan sebuah alat menjadi peak flow meter berbasis Mikrokontroler AT89S51 dilengkapi nilai PEFR Normal/tidak normal, namun masih menggunakan DC Fan sehingga data yang didapat kurang akurat. Kemudian alat tersebut dikembangkan lagi menjadi Peak Flow Meter Digital menggunakan sensor tekanan MPX5100, tetapi masih memiliki kekurangan yaitu belum dapat diaplikasikan dalam penyimpanan data pada SDcard agar memudahkan dokter mengetahui pada detik ke berapa hembusan paling tinggi dari seorang pasien [3].

Penelitian berikutnya yakni penelitian dari Poltekes Surabaya telah membuat rancang bangun "Peak Flow Meter Portable Dilengkapi Dengan SDcard", menggunakan sensor gas MPX5100 dan pengukuran ekspirasi atau arus puncak dideteksi oleh sensor MPX5100. Berdasarkan hasil rancangan tersebut, sensor yang dimanfaatkan tidak sesuai dengan objek yang digunakan. Dalam hal ini diperlukan perubahan objek yang tepat agar sesuai dengan fungsi sensor dan belum menggunakan output suara dan pemantauan history pemeriksaan menggunakan smartphone. Maka dari itu penulis mengembangkan alat tersebut dengan menggunakan sensor MPXV7002DP yang bekerja pada tekanan $-2 \mathrm{kPa}$ sampai $+2 \mathrm{kPa}(-0.3$ psi sampai $+0,3 \mathrm{psi}$ ) atau $0,5 \mathrm{kPa}$ sampai $4,5 \mathrm{kPa}$ dengan tegangan output 0,2 volt sampai 4,7 volt untuk mendeteksi tekanan aliran nafas dari mulut. Mikrokontroler Arduino Nano berfungsi sebagai pusat pengendali yang terhubung dengan sensor MPXV7002DP, LCD dan speaker. LCD digunakan sebagai penampil, speaker sebagai output suara, Micro SD sebagai penyimpanan data hasil pemeriksaan dan Bluetooth HC-5 sebagai penghubung nirkabel ke perangkat android [4].

\section{Peak Flow Meter}

Peak flow meter adalah perangkat genggam, portable yang murah untuk penderita asma, yang digunakan untuk mengukur seberapa baik udara keluar dari paru-paru atau pengukuran arus puncak pada nafas. Mengukur peak flow menggunakan pengukur ini merupakan bagian penting dalam mengelola gejala asma manusia dan mencegah serangan asma, dan akan menjadi bagian dari rencana perawatan asma pribadi manusia. Peak flow meter ini dilengkapi dengan memori untuk penyimpanan data pasien pemeriksaan, dan dapat di akses menggunakan android untuk dapat melihat data hasil pemeriksaan pasien atau history pemeriksaan melalui perangkat android.

Tahap-tahap dalam melakukan pengukuran Arus Puncak Ekspirasi (APE) menggunakan peak flow meter sebagai berikut [5]:

1. Mouthpiece dipasang ke ujung peak flow meter bila perlu.

2. Pasien diposisikan untuk berdiri atau duduk dengan punggung tegak dan pegangan peak flow meter dengan posisi horizontal (mendatar) tanpa menyentuh atau mengganggu gerakan marker. Marker berada pada posisi skala terendah (nol).

3. Pasien dianjurkan menghirup nafas sedalam mungkin. Udara dimasukkan ke mulut dengan bibir menutup rapat mengelilingi mouthpiece, dan udara dibuang segera dan sekuat mungkin.

4. Selanjutnya saat membuang nafas, marker bergerak dan menunjukkan angka pada skala, hasilnya dicatat.

5. Marker dikembalikan pada posisi nol, lalu diulangi langkah $2-4$ sebanyak 3 kali, dan dipilih nilai paling tinggi. Bandingkan dengan nilai terbaik pasien tersebut atau nilai prediksi.

Pada Tabel 1 sampai Tabel 4 berikut ini, secara berturut-turut disajikan nilai Prediksi Arus Puncak Ekspirasi (APE) Normal (L/menit) berdasarkan katagori usia dan jenis kelamin $[6,7]$. 
Tabel 1. Nilai prediksi arus puncak ekspirasi (ape) normal (1/menit) untuk laki-laki

\begin{tabular}{c|c|c|c|c|c}
\hline \multirow{2}{*}{ Umur } & \multicolumn{5}{|c}{ Tinggi $(\mathrm{cm})$} \\
\cline { 2 - 6 } & 152 & 165 & 178 & 191 & 203 \\
\hline 20 & 554 & 575 & 594 & 611 & 626 \\
\hline 25 & 580 & 603 & 622 & 640 & 656 \\
\hline 30 & 594 & 617 & 637 & 655 & 672 \\
\hline 35 & 599 & 622 & 643 & 661 & 677 \\
\hline 40 & 597 & 620 & 641 & 659 & 675 \\
\hline 45 & 591 & 613 & 633 & 651 & 668 \\
\hline 50 & 580 & 602 & 622 & 640 & 656 \\
\hline 55 & 566 & 588 & 608 & 625 & 640 \\
\hline 60 & 551 & 572 & 591 & 607 & 622 \\
\hline 65 & 533 & 554 & 572 & 588 & 603 \\
\hline 70 & 515 & 535 & 552 & 568 & 582 \\
\hline 75 & 496 & 515 & 532 & 547 & 560 \\
\hline
\end{tabular}

Tabel 2. Nilai prediksi arus puncak ekspirasi (ape) normal (1/menit) untuk perempuan.

\begin{tabular}{c|c|c|c|c|c}
\hline \multirow{2}{*}{ Umur } & \multicolumn{5}{|c}{ Tinggi $(\mathrm{cm})$} \\
\cline { 2 - 6 } & 140 & 152 & 165 & 178 & 191 \\
\hline 20 & 444 & 460 & 474 & 486 & 497 \\
\hline 25 & 455 & 471 & 485 & 497 & 509 \\
\hline 30 & 458 & 475 & 489 & 502 & 513 \\
\hline 35 & 458 & 474 & 488 & 501 & 512 \\
\hline 40 & 453 & 469 & 483 & 496 & 507 \\
\hline 45 & 446 & 462 & 476 & 488 & 499 \\
\hline 50 & 437 & 453 & 466 & 478 & 489 \\
\hline 55 & 427 & 442 & 455 & 467 & 477 \\
\hline 60 & 415 & 430 & 443 & 454 & 464 \\
\hline 65 & 403 & 417 & 430 & 441 & 451 \\
\hline 70 & 390 & 404 & 416 & 427 & 436 \\
\hline 75 & 377 & 391 & 402 & 413 & 422 \\
\hline
\end{tabular}

Tabel 3. Nilai prediksi arus puncak ekspirasi (ape) normal (1/menit) untuk anak perempuan.

\begin{tabular}{c|c|c|c|c|c}
\hline \multirow{2}{*}{ Umur } & \multicolumn{5}{|c}{ Tinggi $(\mathrm{cm})$} \\
\cline { 2 - 6 } & 140 & 152 & 165 & 178 & 191 \\
\hline 6 & 245 & 268 & 297 & 327 & 357 \\
\hline 8 & 264 & 287 & 316 & 346 & 376 \\
\hline 10 & 283 & 305 & 335 & 365 & 395 \\
\hline 12 & 302 & 324 & 354 & 384 & 414 \\
\hline 14 & 321 & 343 & 373 & 403 & 432 \\
\hline 16 & 340 & 362 & 392 & 421 & 451 \\
\hline 18 & 358 & 381 & 411 & 440 & 470 \\
\hline 20 & 377 & 400 & 429 & 459 & 489 \\
\hline
\end{tabular}


Tabel 4. Nilai prediksi arus puncak ekspirasi (ape) normal (1/menit) untuk anak laki-laki.

\begin{tabular}{c|c|c|c|c|c}
\hline \multirow{2}{*}{ Umur } & \multicolumn{5}{|c}{ Tinggi $(\mathrm{cm})$} \\
\cline { 2 - 6 } & 152 & 163 & 173 & 183 & 193 \\
\hline 6 & 289 & 336 & 384 & 431 & 479 \\
\hline 8 & 309 & 356 & 404 & 451 & 499 \\
\hline 10 & 329 & 376 & 424 & 471 & 519 \\
\hline 12 & 349 & 396 & 444 & 491 & 539 \\
\hline 14 & 369 & 416 & 464 & 511 & 559 \\
\hline 16 & 389 & 436 & 484 & 531 & 579 \\
\hline 18 & 408 & 456 & 503 & 551 & 599 \\
\hline 20 & 428 & 476 & 523 & 571 & 618 \\
\hline 22 & 448 & 496 & 543 & 591 & 638 \\
\hline 24 & 468 & 516 & 563 & 611 & 658 \\
\hline 25 & 478 & 526 & 573 & 621 & 668 \\
\hline
\end{tabular}

Gambar 1 berikut ini adalah grafik PEF (Peak Expiratory Flow).

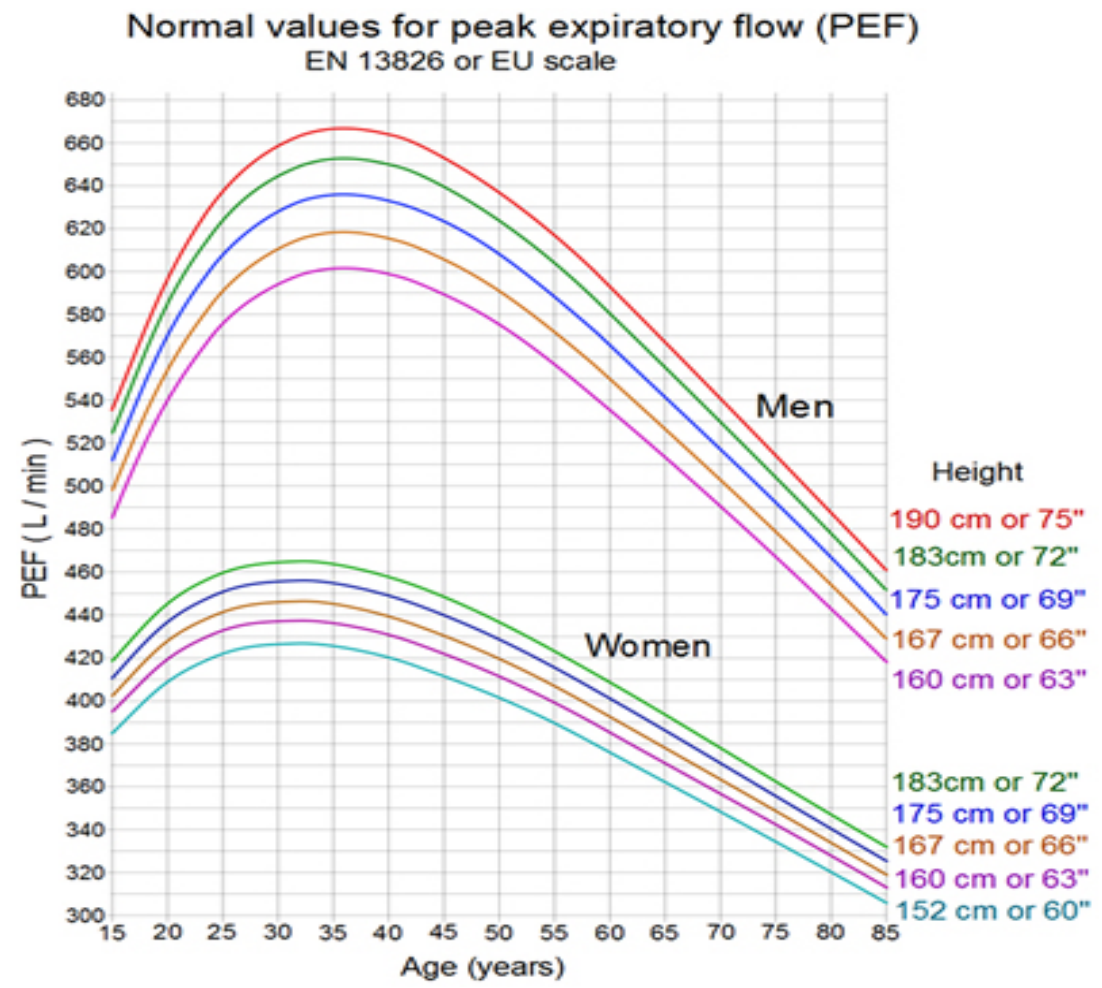

Gambar 1. Grafik PEF

Nilai prediksi normal faal paru setiap orang dipengaruhi oleh banyak faktor seperti gender, tinggi badan, berat badan usia, ras, dan lain-lain. Tim Pneumobile Project Indonesia pada tahun 1992 melakukan penelitian nilai faal paru rata-rata orang Indonesia. Salah satu hasil penelitian tersebut adalah tabel nilai normal PEFR orang Indonesia. Bila tidak tersedia tabel tersebut, dapat juga menggunakan Persamaan (1) dan (2) [8]. 


\section{Laki-laki:}

$$
\begin{aligned}
\text { PEFR }(\mathrm{L} / \mathrm{dtk})= & -10,86040+0,12766 \times \text { Umur }+0,11169 \times \mathrm{TB} \\
& -0,0000319344 \times \text { Umur3 }+1,70935
\end{aligned}
$$

\section{Perempuan:}

$$
\begin{aligned}
\text { PEFR }(\mathrm{L} / \mathrm{dtk})= & -5,12502+0,09006 \times \text { Umur }+0,06980 \times \mathrm{TB} \\
& -0,00145669 \times \text { Umur } 2+1,77692
\end{aligned}
$$

Jika hasil pengukuran di bawah hasil dari tabel normal, maka bisa dikatakan terkena asma. Mengawasi kekambuhan penderita asma dengan menilai APE menggunakan alat tersebut dapat membantu penderita asma menilai berat-ringan serangannya secara lebih objektif. Nilai APE dapat menunjukkan reversibilitas dan variabilitas dalam mendiagnosis penderita asma. Pengukuran nilai APE sebaiknya dibandingkan dengan nilai terbaik sebelumnya, bukan nilai prediksi normal; kecuali tidak diketahui nilai terbaik penderita yang bersangkutan $[9,10,11]$.

\section{Metode Penelitian}

\subsection{Blok Diagram Sistem}

Blok diagram sistem ditunjukkan pada Gambar 2. Pada mulanya sistem akan menginisialisasi. Kemudian penghembusan nafas sebagai input akan dibaca oleh sistem. Dalam perancangan alat ini menggunakan sensor MPXV7002DP untuk mendeteksi tekanan aliran nafas dari mulut. Mikrokontroler arduino Nano berfungsi sebagai pusat pengendali yang terhubung dengan sensor MPXV7002DP, LCD dan speaker. LCD digunakan sebagai penampil, speaker sebagai output suara, SDCard sebagai penyimpanan data hasil pemeriksaan dan Bluetooth HC-5 sebagai penghubung nirkabel ke perangkat android. User dapat mengulangi kembali pendeteksian dengan menekan tombol reset atau menonaktifkan alat tersebut.

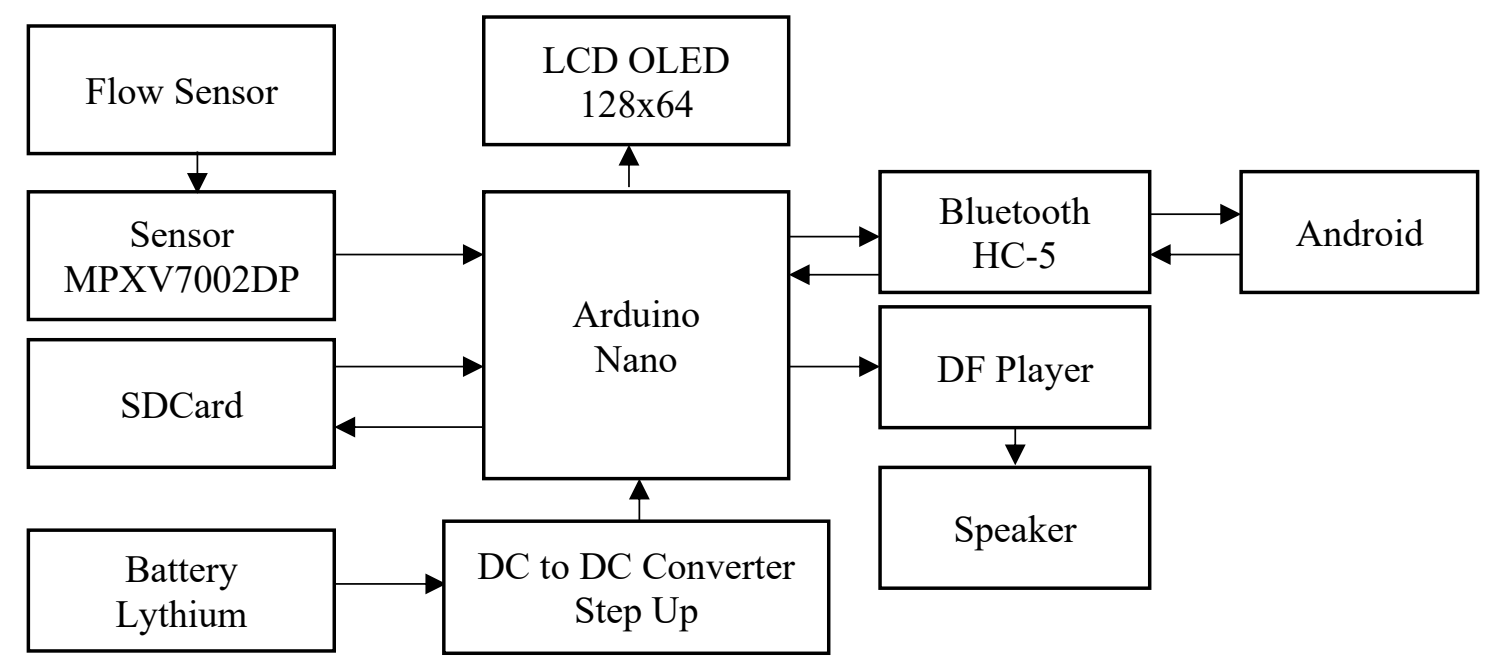

Gambar 2. Blok diagram sistem 


\subsection{Perancangan Peak Flow Meter}

Hasil dari perancangan skematik Peak Flow Meter dengan output suara dapat dilihat pada Gambar 3.

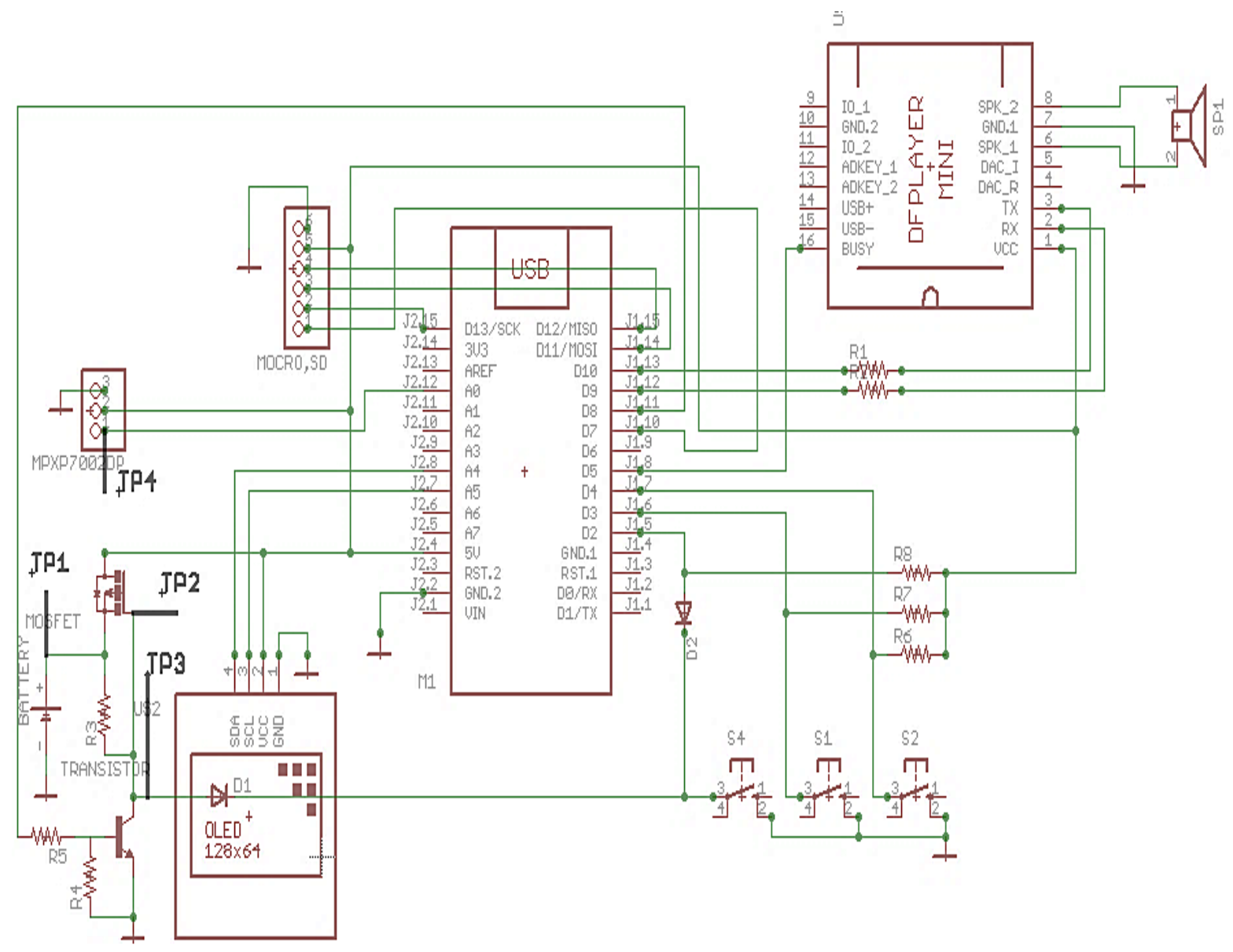

Gambar 3. Gambar skematik Peak Flow Meter

Pada saat alat mati, untuk menghidupkannya tekan tombol power, ketika tombol power ditekan kaki gate Q1/ Mosfet tipe P akan berkondisi rendah atau low. Sehingga arus dari battery akan mengalir keseluruh rangkaian kemudian program di arduino akan melakukan inisialisasi dan akan memberikan logic high pada pin D8 sehingga transistor Q2 akan ON. Fungsi dari transistor Q2 untuk mengunci supaya Q1 terus dalam kondisi ON. Setelah itu arduino akan membaca sensor MPXV7002DP yang kemudian dikonversi nilai analog digital converter(ADC) dan selanjutnya di konversi lagi kedalam bentuk Liters per minute (1/min) dan kemudian ditampilkan di OLED display. Saat pembacaan sensor selesai maka arduino akan memerintahkan DF Player untuk memutar suara.

\subsection{Diagram Alir Proses Program}

Gambar 4 menunjukkan diagram alir software yang diawali dengan menekan tombol power untuk menghidupkan alat kemudian sistem akan menginisialisasi. Kemudian akan keluar Tampilan SDcard OK, lalu akan otomatis pindah ke menu pengimputan data diri, yang di dalamnya ada pengimputan usia, tinggi badan dan jenis kelamin. Kemudian penyesuaian data yang di-input. 


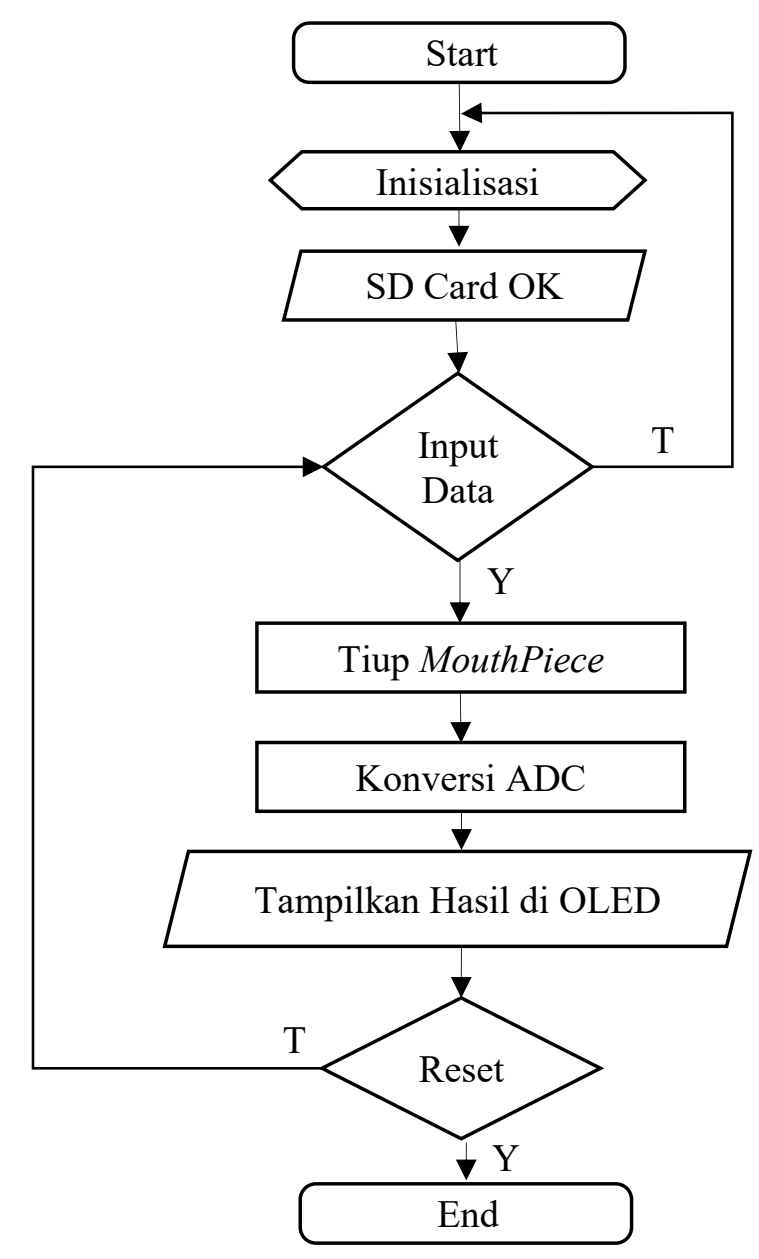

Gambar 4. Diagram Alir Proses/Program

Sensor MPXV7002DP akan aktif apabila push button/tombol start ditekan untuk memulai pengecekan arus puncak nafas/ekspirasi dengan meniup sekuat kuatnya. Arduino digunakan sebagai pusat pengendali sistem. Hasil pembacaan sensor dikonversi ke dalam data keluaran ADC dan diubah lagi ke dalam bentuk Liters per minute (1/min). OLED akan menampilkan nilai hasil pengukuran arus puncak nafas. Speaker berfungsi sebagai output suara dari hasil pemeriksaan arus puncak nafas/ekspirasi. Sementara itu, tombol reset berfungsi untuk mengulang program kembali.

\subsection{Flow Sensor Hamilton}

Penelitian ini menggunakan Flow Sensor Hamilton yang dapat mendeteksi flow/aliran gas yang akan masuk ke pasien. Flow sensor ini juga berfungsi sebagai sensor agar Minute Volume dan Tidal Volume untuk pasien itu sesuai dengan kebutuhan dan sensor ini juga tidak membutuhkan daya. Bentuk fisik flow sensor Hamilton seperti yang ditunjukkan dalam Gambar 5. 


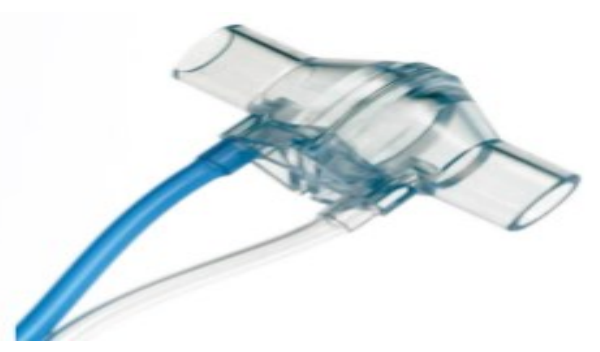

Gambar 5. Flow Sensor Hamilton

Flow sensor Hamilton ini mempunya tingkat keakurasian yang cukup tinggi seperti

$\begin{array}{ll}\text { Akurasi } & : \pm 10 \%, \\ \text { Tingkatan resistensi } & :<2.5 \mathrm{mbar}, \\ \text { Kisaran tekanan } & : \pm 100 \mathrm{mbar}, \\ \text { Suhu pengoperasian } & : 15-40^{\circ} \mathrm{C}\end{array}$

\subsection{Sensor Tekanan MPXV7002DP}

Sensor tekanan gas yang digunakan adalah strain gauge dengan tipe MPXV7002DP. Ini merupakan sensor tekanan yang peka terhadap tekanan rendah. Hanya dengan tiupan saja dapat mempengaruhi tegangan output yang dihasilkan. Sensor ini menggunakan bahan Silicon Stress Stain Gauge. MPXV7002DP adalah Strain gauge jenis piezoresistif tranducer berbahan silicon yang terintegrasi dalam sebuah chip, bekerja pada tekanan $-2 \mathrm{kPa}$ sampai +2 $\mathrm{kPa}(-0.3$ psi sampai $+0.3 \mathrm{psi})$ atau $0.5 \mathrm{kPa}$ sampai $4.5 \mathrm{kPa}$ dengan tegangan output 0,2 volt sampai 4,7 volt [12]. Gambar 6 dan Gambar 7 berikut ini menunjukkan bentuk fisik dan penampang Pin-Out dari sensor MPXV7002DP.

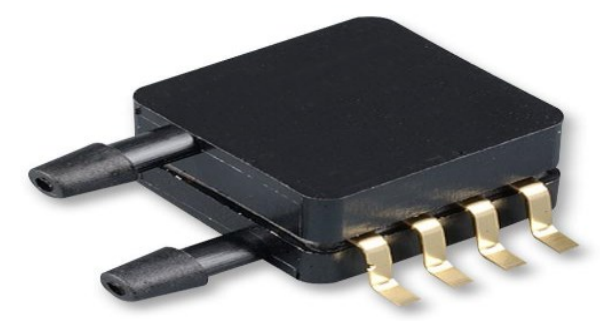

Gambar 6. Sensor MPXV7002DP

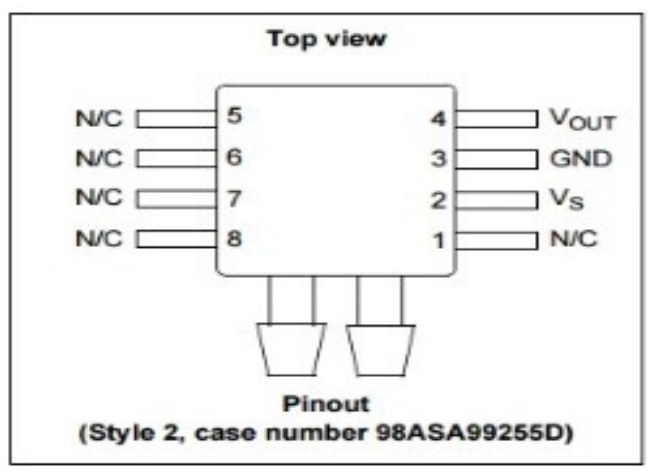

Gambar 7. Pin-Out sensor MPXV7002DP 


\subsection{DF Player}

Modul mini DF Player adalah modul MP3 serial yang menyediakan MP3, WMV hardware terintegrasi yang sempurna. Sedangkan perangkat lunaknya mendukung driver kartu TF, mendukung sistem file FAT16, FAT32. Melalui perintah serial sederhana untuk menentukan permainan musik, serta cara bermain musik dan fungsi lainnya, tanpa operasi dasar yang rumit, mudah digunakan, stabil dan handal adalah fitur yang paling penting dari modul ini.

Berikut merupakan spesifikasi DF Player.

1. Fitur pendukung

a. MP3 dan WMV decoding

b. Dukungan sampling rate $8 \mathrm{kHz}, 11.025 \mathrm{kHz}, 12 \mathrm{kHz}, 16 \mathrm{kHz}, 22.05 \mathrm{kHz}, 24$ $\mathrm{kHz}, 32 \mathrm{kHz}, 44.1 \mathrm{kHz}, 48 \mathrm{kHz}$

c. Output DAC 24-bit, dukungan rentang dinamis 90dB, SNR mendukung 85dB

d. Mendukung FAT16, sistem file FAT32, dukungan maksimal kartu TF 32GB

e. Berbagai mode kontrol, mode serial, mode kontrol tombol AD

f. Fitur bahasa siaran itu, dapat menghentikan sebentar musik latar yang sedang dimainkan

g. Amplifier 3W built-in Data audio diurutkan berdasarkan folder mendukung hingga 100 folder, setiap folder bisa ditugaskan ke 1000 lagu

2. Aplikasi

h. 30 tingkat volume disesuaikan, 10 level EQ disesuaikan.

a. Navigasi suara navigasi mobil.

b. Inspektur transportasi jalan.

c. Mobil wisata listrik.

d. Alarm kegagalan peralatan elektromekanik.

e. Suara alarm kebakaran.

f. Peralatan siaran otomatis, siaran biasa.

3. Pin DF player

Pin DF player ditunjukkan Gambar 8. Sedangkan deskripsi fungsi pada setiap Pin DF seperti yang disajikan pada Tabel 5 .

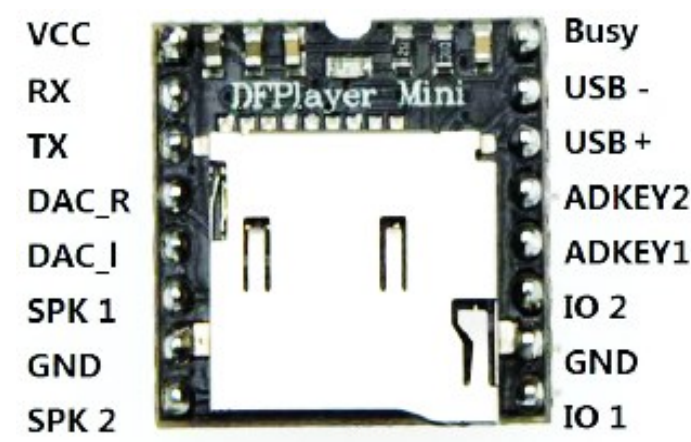

Gambar 8. Pin DF Player 
Tabel 5. Fungsi pada kaki DF player.

\begin{tabular}{c|c|c|c}
\hline No & Pin & Description & Note \\
\hline 1 & VCC & Input voltage & DC 3,2-5 V; Type DC 4,2 V \\
\hline 2 & RX & UART serial input & \\
\hline 3 & TX & UART serial output & \\
\hline 4 & DAC_R & Audio output right chanel & Drive earphone and amplifier \\
\hline 5 & DAC_L & Audio output left chanel & Drive earphone and amplifier \\
\hline 6 & SPK2 & Speaker - & Drive speaker less than 3W \\
\hline 7 & GND & Ground & Power GND \\
\hline 8 & SPK1 & Speaker + & Drive speaker less than 3W \\
\hline 9 & IO 1 & Trigger Port 1 & Short press to play previous \\
\hline 10 & GND & Ground & Power GND \\
\hline 11 & IO 2 & Trigger Port 2 & Short press to play next \\
\hline 12 & ADKEY 1 & AD Port 1 & Trigger play first segment \\
\hline 13 & ADKEY 2 & AD Port 2 & Trigger play fifth segment \\
\hline 14 & USB+ & USB + DP & USB port \\
\hline 15 & USB- & USB - DM & USB port \\
\hline 16 & BUSY & Playing status & Low means playing/high means no \\
\hline
\end{tabular}

\subsection{Modul Bluetooth HC-05}

Bluetooth adalah protokol komunikasi wireless yang bekerj pada frekuensi $2,4 \mathrm{GHz}$ untuk pertukaran data pada perangkat bergerak seperti PDA, laptop, smartphone dan lainlain. Modul Bluetooth HC-05 terdiri dari 6 pin konektor, yang setiap pinnya memiliki fungsi yang berbeda. Untuk gambar modul Bluetooth dan konfigurasi pinnya dapat dilihat pada Gambar 9.

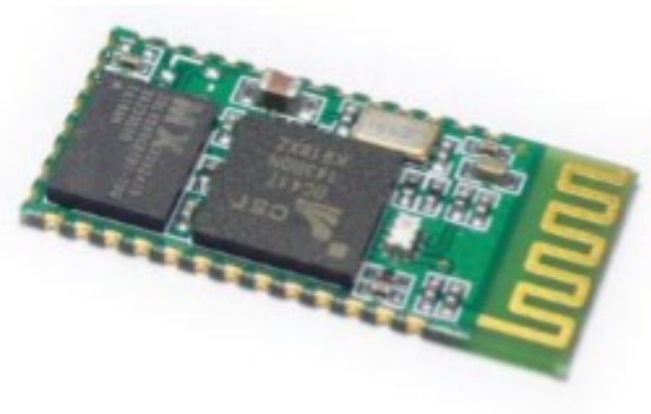

Gambar 9. Bluetooth HC-05

Modul Bluetooth HC-05 dengan supply tegangan sebesar 3,3 V ke pin 12 modul Bluetooth sebagai VCC. Pin 1 pada modul Bluetooth sebagai transmitter. Kemudian pin 2 pada modul Bluetooth sebagai receiver. Tabel 6 berikut ini menunjukkan jumlah pin pada modul Bluetooth HC-05 beserta tipe dan kegunaannya. 
Tabel 6. Pin-out Bluetooth HC-05

\begin{tabular}{c|c|c|l}
\hline PIN & PIN\# & PAD type & \multicolumn{1}{c}{ Description } \\
\hline GND & $13,21,22$ & VSS & Ground pot \\
\hline 3.3 VCC & 12 & $3.3 \mathrm{~V}$ & $\begin{array}{l}\text { Integrated 3.3 V } \\
(+) \text { supply with on-chip linier regulator } \\
\text { output within 3,15-3,3 V }\end{array}$ \\
\hline AIO0 & 9 & Bi-directional & Programmable input/output line \\
\hline AIO1 & 10 & Bi-directional & Programmable input/output line \\
\hline PIO0 & 23 & $\begin{array}{c}\text { Bi-directional } \\
\text { RX EN }\end{array}$ & $\begin{array}{l}\text { Programmable input/output line } \\
\text { Control output for LNA(if fitted) }\end{array}$ \\
\hline PIO1 & 24 & $\begin{array}{c}\text { Bi-directional } \\
\text { TX EN }\end{array}$ & $\begin{array}{l}\text { Programmable input/output line } \\
\text { Control output for PA(if fitted) }\end{array}$ \\
\hline
\end{tabular}

\subsection{Blynk}

Blynk adalah IoT (Internet Of Things) Cloud platform untuk aplikasi iOS dan Android yang berguna untuk mengontrol Arduino, Raspberry Pi, dan board-board sejenisnya melalui Internet. Blynk adalah dashboard digital yang dapat membangun sebuah antarmuka grafis untuk alat yang telah dibuat hanya dengan menarik dan menjatuhkan sebuah widget. Blynk sangat mudah dan sederhana untuk mengatur semuanya dan hanya dalam waktu kurang dari 5 menit. Blynk tidak terikat dengan beberapa microcontroller tertentu atau shield tertentu. Sebaliknya, apakah Arduino atau Raspberry Pi melalui Wi-Fi, Ethernet atau chip ESP8266, Blynk akan membuat alat online dan siap untuk Internet Of Things $[13,14,15]$. Tampilan aplikasi blynk seperti ditujukan dalam Gambar 10.

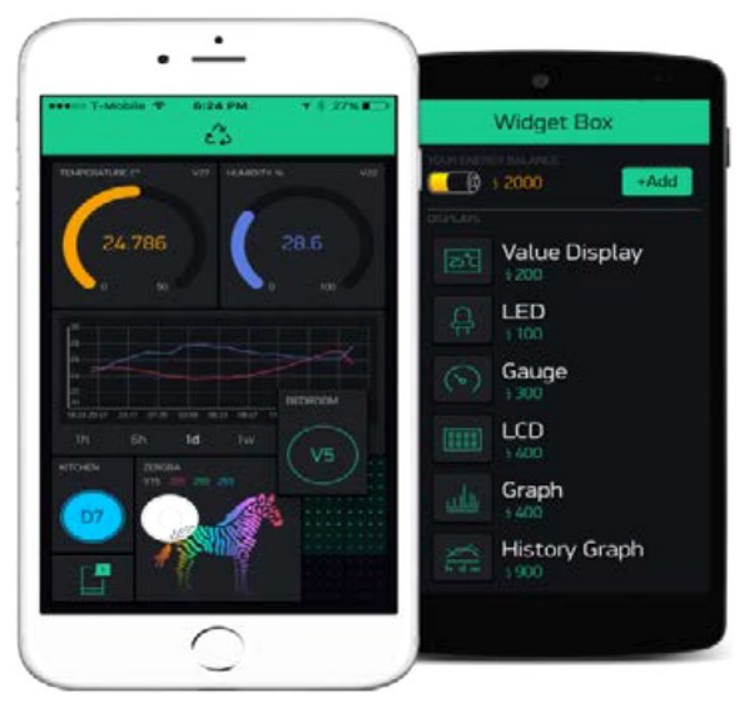

Gambar 10. Aplikasi Blynk.

\section{Hasil Pengujian dan Analisis}

\subsection{Pengujian Pada Kaki Mosfet Saat ON/OFF}

Pengukuran dilakukan pada kaki drain mosfet menggunakan multimeter digital dengan cara mengukur tegangan DC saat alat ON dan OFF. Hasil pengujian seperti ditunjukan dalam Tabel 7. 
Tabel 7. Hasil Pengukuran Mosfet

\begin{tabular}{c|c|c}
\hline \multicolumn{2}{c|}{ Hasil Pengukuran } & Tegangan Kerja Datasheet \\
\hline Keadaan & Tegangan $(\mathrm{V})$ & \multirow{2}{*}{ Max } \\
\cline { 1 - 2 } On & 3,83 & 1. Drain-Source Voltage : VDS $=-20$ \\
\hline Off & 0 & 2. Gate-Source Voltage : VGS $= \pm 8 \mathrm{~V}$ \\
\hline On & 3,83 & \\
\hline Off & 0 & \\
\hline
\end{tabular}

Tabel di atas menunjukan bahwa jika push button ditekan, maka kaki gate akan terhubung ke ground dan tegangan dari battery akan masuk ke kaki source dan mengalir ke kaki drain atau mosfet berkondisi rendah low (0). Sedangkan jika push button tidak ditekan maka tegangan dari Battery tidak akan masuk atau mosfet berkondisi high (1). Dengan demikian dapat dikatakan bahwa mosfet sudah bekerja dengan baik.

\subsection{Pengujian Pada Transistor pada saat ON/OF}

Pengukuran dilakukan dengan mengukur tegangan DC pada kaki collector transistor menggunakan multimeter digital. Hasil pengukuran disajikan pada Tabel 8.

Tabel 8. Hasil Pengukuran Transistor

\begin{tabular}{c|c|c}
\hline \multicolumn{2}{c|}{ Hasil Pengukuran } & $\begin{array}{c}\text { Tegangan Kerja kaki base } \\
\text { Datasheet }\end{array}$ \\
\hline Keadaan & Tegangan vdc & \multicolumn{1}{|c}{} \\
\hline On & 0 & \multirow{2}{*}{$0,2 \mathrm{~V}$} \\
\hline Off & 3,83 & \\
\hline On & 0 & \\
\hline Off & 3,83 & \\
\hline
\end{tabular}

Fungsi dari transistor untuk mengunci supaya mosfet terus dalam kondisi ON. Jika mosfet berkondisi Low (0), maka tegangan akan masuk ke arduino untuk inisialisasi sehingga memberikan kondisi high pada pin D8 arduino, maka kaki Base pada transistor akan ON. Tegangan minimum untuk mengaktifkan transistor yaitu 0,2 Vdc. Dengan demikian dapat dikatakan bahwa transistor pada alat berfungsi dengan baik.

\subsection{Kalibrasi Alat Menggunakan Medical Gas Flow Analyzer}

Pengujian dilakukan dengam membandingkan alat rancang bangun ini dengan alat kalibrasi Medical Gas Flow Analyzer merk FLUKE dengan tipe VT Mobile. Dengan berpedoman pada metode kerja VT Mobile maka proses pengujian ini dilakukan dengan mencatat hasil pengukuran sebanyak 5 kali sebagaimana disajikan dalam Tabel 9 di bawah ini. Display hasil pembacaan pada alat sebagaimana ditunjukkan dalam Gambar 11.

Rancang bangun Peak Flow Meter menggunakan mikrokontroler Arduino Nano. Sensor MPXV7002DP digunakan sebagai pengukuran tekanan hembusan nafas. kemudian hasil pembacaan sensor di keluarkan berupa output suara, ditampilkan di Oled Display dan di tampilkan di smartphone menggunakan aplikasi blynk. 


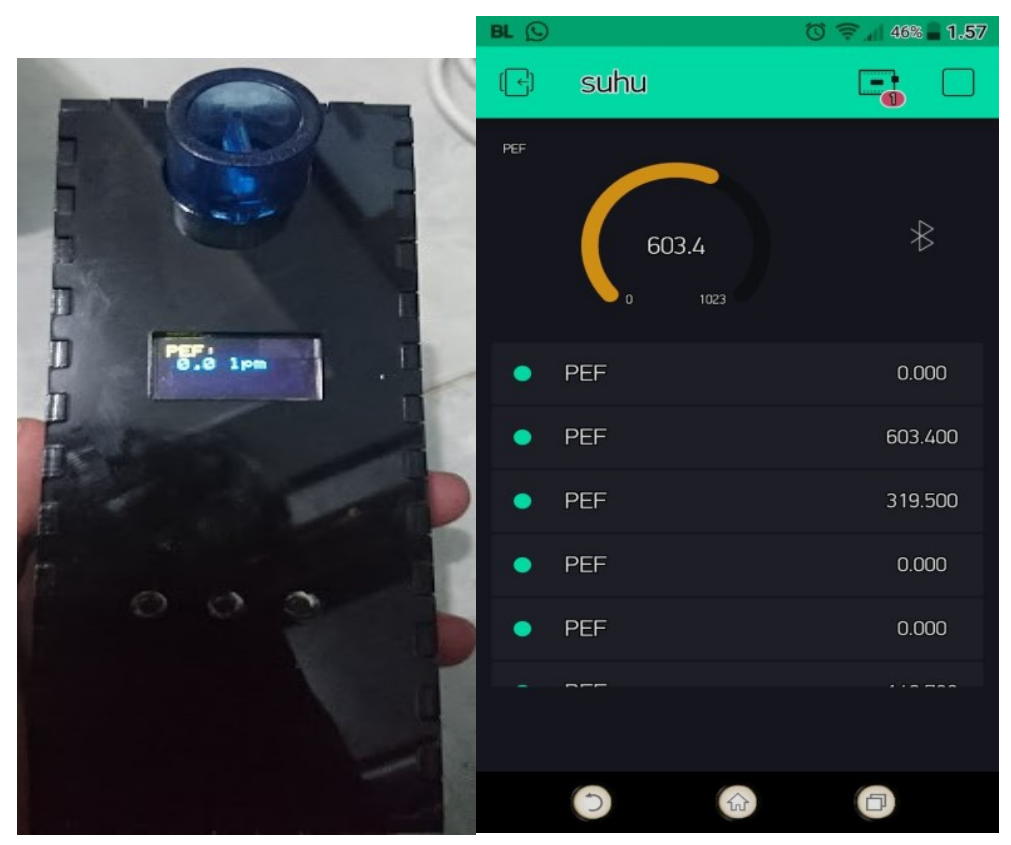

Gambar 11. Display Hasil Pembacaan Alat

Tabel 9. Pengujian alat Peak Flow Meter dengan VT Mobile

\begin{tabular}{|c|c|c|c|c|c|c|c|}
\hline \multirow[b]{2}{*}{ No } & \multicolumn{2}{|c|}{ Peak Flow Mater } & \multicolumn{2}{|c|}{ VT Mobile } & \multicolumn{2}{|c|}{ Kesalahan (\%) } & \multirow{2}{*}{$\begin{array}{c}\text { Toleransi } \\
(\%)\end{array}$} \\
\hline & Hasil & Rata-rata & Hasil & Rata-rata & $(\%)$ & Rata-rata & \\
\hline 1 & $98,1 \mathrm{lpm}$ & \multirow{5}{*}{78,48} & $96,98 \mathrm{lpm}$ & \multirow{5}{*}{77,74} & $1,1 \%$ & \multirow{5}{*}{1,54} & $10 \%$ \\
\hline 2 & $68,01 \mathrm{pm}$ & & $67,751 \mathrm{pm}$ & & $0,3 \%$ & & $10 \%$ \\
\hline 3 & $69,31 \mathrm{pm}$ & & $70,541 \mathrm{pm}$ & & $1,7 \%$ & & $10 \%$ \\
\hline 4 & $64,01 \mathrm{pm}$ & & $62,501 \mathrm{pm}$ & & $2,4 \%$ & & $10 \%$ \\
\hline 5 & $93,01 \mathrm{pm}$ & & $90,951 \mathrm{pm}$ & & $2,2 \%$ & & $10 \%$ \\
\hline
\end{tabular}

Dari data di atas dapat dilihat bahwa hasil prosentase kesalahan terbesar yaitu 2,4\% , dimana prosentase kesalahan terbesar yaitu laju hembusan pada alat sebesar 64,0 lpm dan laju hembusan pada VT mobile sebesar $62,50 \mathrm{lpm}$ dengan toleransi $10 \%$. Dan prosentase kesalahan terendah yaitu $0,3 \%$ di mana prosentase kesalahan terendah yaitu laju hembusan pada alat rancang bangun sebesar 68,0 lpm dan laju hembusan pada VT mobile sebesar 67,75 lpm dengan toleransi $10 \%$. Dimana perbedaan hasil pembacaan alat dapat dipengaruhi oleh kekuatan hembusan nafas seseorang, sehingga dapat mempengaruhi hasil pembacaan dari sensor. Dari data tersebut menunjukkan bahwa alat hasil penelitian ini sangat baik dan laik pakai.

\section{Kesimpulan}

Berdasarakan hasil penelitian yang telah diuraikan dapat disimpulkan bahwa sensor MPXV7002DP ini bekerja saat sensor menerima hembusan udara dari flow sensor yang menuju sensor MPXV7002DP. Sensor akan secara otomatis membaca berapa tekanan udara tertinggi dari hembusan nafas. Hasil pengujian menggunakan VT Mobile Medical Gas Flow Analyzer membuktikan persentase error terbesar adalah $2.4 \%$, dengan nilai blowing pada Peak Flow Meter $64.0 \mathrm{lpm}$ dan kecepatan blowing pada VT mobile adalah $62.50 \mathrm{lpm}$. Sedangkan prosentase kesalahan terendah yaitu $0,3 \%$ dengan nilai blowing sebesar $68,0 \mathrm{lpm}$ 
dan kecepatan blowing pada VT mobile sebesar 67,75 lpm. Dengan demikian alat hasil penelitian ini laik dan memenuhi syarat digunakan untuk mendeteksi penyakit asma.

\section{Daftar Pustaka}

[1] Setiyarini, T., Abi Muhlisin, S. K. M., Kep, M., Zulaicha, E., \& Kp, S. (2016). Efektivitas Pendidikan kesehatan menggunakan media leaflet dan penyuluhan individual terhadap pengetahuan pencegahan kekambuhan asma (Doctoral dissertation, Universitas Muhammadiyah Surakarta).

[2] Lorensia, A., De Queljoe, D., \& Santosa, K. A. (2017). Kelengkapan informasi mengenai cara penggunaan peak flow meter yang diberikan kepada pasien asma di apotek. Jurnal Ilmiah Manuntung, 1(2), 200-206.

[3] Suryowinoto, A., Hamid, A., \& Desmalasa, A. F. (2017). Deteksi Dini Penyakit Pernafasan Asma Dengan Peak Expiratory Flow Meter Berbasis Microcontroller. Jurnal Mikrotek, 2(4).

[4] Anisa, A., Hamzah, T., \& Mak'ruf, M. R. (2020). Peak Flow Meter with Measurement Analysis. Indonesian Journal of electronics, electromedical engineering, and medical informatics, 2(3), 107-112.

[5] Adeniyi, B. O., \& Erhabor, G. E. (2011). The peak flow meter and its use in clinical practice. Afr J Respir Med, 6(2), 5-7.

[6] Gregg, I., \& Nunn, A. J. (1973). Peak expiratory flow in normal subjects. $\mathrm{Br}$ Med $J, 3(5874), 282-284$.

[7] Setyaningtyas, L., Herawati, I., \& Fis, S. (2016). Penatalaksanaan Fisioterapi Pada Penderita Asma Bronkiale Di Rumah Sakit Khusus Paru Respira Yogyakarta (Doctoral dissertation, Universitas Muhammadiyah Surakarta).

[8] Novarin, C., Murtaqib, M., \& Widayati, N. (2015). Pengaruh Progressive Muscle Relaxation terhadap Aliran Puncak Ekspirasi Klien dengan Asma Bronkial di Poli Spesialis Paru B Rumah Sakit Paru Kabupaten Jember (The Effect of Progressive Muscle Relaxation on Peak Expiratory Flow of Clients with Bronchial As. Pustaka Kesehatan, 3(2), 311-318.

[9] Sundaru, H. (2007). Apa yang Diketahui Tentang Asma. Departemen Ilmu Penyakit Dalam, FKUI/RSCM, 4.

[10] ISKANDAR, S. (2011). Faktor-Faktor Risiko Yang Berpengaruh Terhadap Kejadian Asma Pada Anak Di Kota Semarang (Doctoral dissertation, Diponegoro University).

[11] Arvin, B. K. (2000). Ilmu kesehatan anak. EGC.

[12] Package, T. P. S. M., \& Gauge, P. S. S. S. S. (2005). MPXV7002 Integrated Silicon Pressure Sensor On-Chip Signal Conditioned, Temperature Compensated and Calibrated.

[13] SETIAWAN, E. J. (2017). Rancang bangun IoT temperature controller untuk enclosure BTS berbasis microcontroller wemos dan android (Doctoral dissertation, Universitas Mercu Buana).

[14] Prayogo, I., Alfita, R., \& Wibisono, K. A. (2017). Sistem Monitoring Denyut Jantung Dan Suhu Tubuh Sebagai Indikator Level Kesehatan Pasien Berbasis Iot (Internet Of Thing) Dengan Metode Fuzzy Logic Menggunakan Android. Jurnal Teknik Elektro dan Komputer TRIAC, 4(2), 33-39.

[15] Swaminathan, S., Venkatesan, P., \& Mukunthan, R. (1993). Peak expiratory flow rate in south Indian children. Indian pediatrics, 30(2), 207-11. 